\title{
Siolmatra brasiliensis (Cogn.) Baill., Cucurbitaceae, acute toxicity in mice
}

\author{
Aliny P. Lima, ${ }^{1}$ Carlos E. S. Barbosa, ${ }^{1}$ Flávia C. Pereira, ${ }^{1}$ Cesar A. S. T. Vilanova-Costa, ${ }^{1}$ \\ Alessandra S. B. B. Ribeiro, ${ }^{1}$ Hugo D. Silva, ${ }^{1}$ Neucirio R. Azevedo, ${ }^{2}$ Vera L. Gomes-Klein, ${ }^{3}$ \\ Elisângela P. Silveira-Lacerda ${ }^{*}, 1$
}

${ }^{1}$ Laboratório de Genética Molecular e Citogenética, Instituto de Ciências Biológicas, Universidade Federal de Goiás, Rua Estrada do Campus s/n Campus Samambaia (Campus II) 74001-970 Goiânia-GO, Brazil,

${ }^{2}$ Laboratório de Produtos Naturais, Instituto de Química, Universidade Federal de Goiás, Rua Estrada do Campus s/n Campus Samambaia (Campus II) 74001-970 Goiânia-GO, Brazil,

${ }^{3}$ Laboratório de Morfologia e Taxonomia Vegetal, Instituto de Ciências Biológicas, Universidade Federal de Goiás, Goiânia, Rua Estrada do Campus s/n Campus Samambaia (Campus II) 74001-970 Goiânia-GO, Brazil.

\begin{abstract}
RESUMO: "Toxicidade aguda de Siolmatra brasiliensis (Cogn.) Baill., Cucurbitaceae, em camundongos". Siolmatra brasiliensis (Cogn.) Baill., Cucurbitaceae, popularmente conhecida como "pluméria" ou "taiuiá" é utilizada na medicina popular brasileira para diversos fins terapêuticos. O estudo de toxicidade aguda do extrato bruto etanólico (EBE) de Siolmatra brasiliensis foi investigado em camundongos. Nenhuma mortalidade ou sinais de toxicidade foram observados nas doses de 10 e $100 \mathrm{mg} / \mathrm{kg}$, entretanto em doses administradas de $1000 \mathrm{e}$ $2000 \mathrm{mg} / \mathrm{kg}$ levou as diversas alterações comportamentais e mortalidade. A DL50 para o EBE foi de $1000 \mathrm{mg} / \mathrm{kg}$. Análise macroscópica dos órgãos demonstrou alterações morfológicas no coração dos animais tratados com 1000 e $2000 \mathrm{mg} / \mathrm{kg}$. Por meios destes resultados conclui-se que o EBE de Siolmatra brasiliensis é seguro em doses de 10 and $100 \mathrm{mg} / \mathrm{kg}$ e apresentou toxicidade nas doses de 1000 e $2000 \mathrm{mg} / \mathrm{kg}$.
\end{abstract}

Unitermos: Siolmatra brasiliensis, toxicidade, camundongo, Cucurbitaceae.

\begin{abstract}
Siolmatra brasiliensis (Cogn.) Baill., Cucurbitaceae, commonly known as "pluméria" or "taiuiá", is widely used in different ways in Brazilian popular medicine to treat several diseases. Acute toxicity of Siolmatra brasiliensis crude ethanolic extract (CEE) was investigated in mice. No mortality or signs of CEE toxicity were observed at the doses of 10 and $100 \mathrm{mg} / \mathrm{kg} \mathrm{bw}$, but the administration of 1000 and $2000 \mathrm{mg} / \mathrm{kg} \mathrm{bw}$ caused several adverse behavioral effects and mortality. Macroscopic inspection of the organs showed morphologic alterations in the heart of animals treated with doses of 1000 and $2000 \mathrm{mg} / \mathrm{kg} \mathrm{bw}$. According to our results, $S$. brasiliensis CEE has an LD50 of $1000 \mathrm{mg} / \mathrm{kg} b w$. We conclude that $S$. brasiliensis CEE was safe at the doses of 10 and $100 \mathrm{mg} / \mathrm{kg} \mathrm{bw}$ and presented toxicity at the doses of 1000 and $2000 \mathrm{mg} / \mathrm{kg} \mathrm{bw}$.
\end{abstract}

Keywords: Siolmatra brasiliensis, toxicity, mice, Cucurbitaceae.

\section{INTRODUCTION}

A Word Health Organization survey indicated that about $65-80 \%$ of the world's population relies on non-conventional medicine, mainly of herbal source, in their primary healthcare (Calixto, 2000). Nevertheless, various plants used in folk medicine still need better quality control since scientific reports indicate they can present bioactive principles that may cause adverse effects (Calixto, 2000; Capasso et al., 2000). Consequently, in order to certify their safety and efficacy, all the products employed in alternative medicine should be evaluated using the same methods applied to test new synthetic drugs (Talalay \& Talalay, 2001).

Many species of the Cucurbitaceae family are edible (fruit) or used for medicinal purposes (roots, leaves, and fruits), whereas others are highly toxic (Gomes-Klein, 1996). The frequent occurrence of core substances, named cucurbitacins, in members of the family Cucurbitaceae has been reported (Cronquist, 
1992; Heywood, 1979). These compounds, responsible for the bitter tang of roots and stems of some species of this family, have been proven both to be highly toxic (Siqueira et al., 2009) and to present biological activity as antitumor agents, fertility inhibitor, purgative, and attractive to insects (Simões et al., 1998).

Thus, aiming to continue this line of research, we have been developing pioneer studies on the bactericide (Almeida et al., 2004), antitumor and cytotoxic properties of Siolmatra brasiliensis (Cogn.) Baill., Cucurbitaceae (Lima et al., 2006), a plant species that occurs in wet forests, at low elevations, from eastern Peru to northwestern Argentina, eastern Paraguay and eastern Brazil (Robinson \& Wunderlin, 2005). According to traditional knowledge, this plant species, commonly known as "pluméria" or "taiuiá" in the state of Goiás, is widely used in different ways in popular medicine to treat several diseases, mainly due to its pharmacological action as an antitumor and antivenom agent (data not published). Balbachas (1959) reports the popular use of $S$. brasiliensis, as well as other plants of the Cucurbitaceae family, is widely variable and is often consumed in the form of potions.

However, to the best of our knowledge, so far there are no documented pharmacological and toxicological studies that can be used to ascertain and regulate these claims. The purpose of this study was to investigate the acute toxicity of the crude ethanolic extract (CEE) of $S$. brasiliensis in order to evaluate its safety for human use.

\section{MATERIAL AND METHODS}

\section{Plant material and preparation of crude ethanolic extract}

Samples of Siolmatra brasiliensis (Cogn.) Baill., Cucurbitaceae, were collected in November 2004, near Potreiro stream, on a private farm named Fortaleza Castelo, located in the municipality of Castelândia $\left(18^{\circ} 03^{\prime} 52.53^{\prime \prime S}, 50^{\circ} 12^{\prime} 13.94^{\prime \prime} \mathrm{W}\right)$, in the state of Goiás, Brazil. The plant material was collected and identified by Prof. Dr. Vera L. Gomes-Klein, and a specimen voucher (UFG 27.510) was deposited in the Herbarium of the Universidade Federal de Goiás.

The stems of this plant species were dried in a hothouse at $45^{\circ} \mathrm{C}$ with forced circulation and air renewal for $96 \mathrm{~h}$, pulverized in a mill, and the resulting powder $(850 \mathrm{~g})$ was percolated with ethanol $(96 \%$, Merck) for $24 \mathrm{~h}$. This extraction procedure was repeated three times and the extract was concentrated in vacuo in a rotative evaporator, yielding $65 \mathrm{~g}$ of $S$. brasiliensis CEE. In the present work, we choose the ethanolic extract of $S$. brasiliensis because its results were compatible with the contents of the potions popularly used, which makes use of ethyl alcohol in the form cachaça (a liquor beverage made from fermented sugarcane) or white wine.

\section{Animals}

This study was approved by the Human and Animal Research Ethics Committee of the Federal University of Goiás. A total of thirty healthy, 8-10 week old male outbred Balb/c mice (Mus musculus) were obtained from the Central Animal House of the Universidade Federal de Goiás, weighing 25-30 g each. They were separated in five groups of six animals each and kept in the Molecular Genetics and Cytogenetics Laboratory, at the same university, in plastic cages $(40 \times 30 \times 16 \mathrm{~cm})$ at standard conditions, in air-conditioned rooms at $22 \pm 2{ }^{\circ} \mathrm{C}$ and $50 \pm 10 \%$ of relative humidity, with a $12 \mathrm{~h}$ light-dark natural cycle. They were fed ad libitum on a standard diet (appropriate commercial rodent diet Labina, Ecibra Ltda.) and had free access to water throughout the period of experimentation.

\section{Acute intraperitoneal toxicity and behavioral activity tests}

The acute toxicity study of $S$. brasiliensis CEE was performed as described by Vogel \& Vogel (1997). The CEE was dissolved in saline solution $0.9 \%$ at four different concentrations $(10,100,1000$, and $2000 \mathrm{mg} / \mathrm{kg} \mathrm{bw})$ and $300 \mu \mathrm{L}$ /animal were administered intraperitoneally in single doses. The vehicle-control group (dose 0) received only equal volumes of saline solution. The animals were observed 5, 15, 60, 120, 240, and $1440 \mathrm{~min}$ after CEE administration and we recorded the following toxicity parameters: urination, defecation, piloerection, motor activity, ataxia, righting reflex, muscular tonus, eyelid ptosis, and death. All the animals were euthanized by cervical dislocation $24 \mathrm{~h}$ after the administration of $S$. brasiliensis CEE and their organs (liver, heart, kidney, lungs, and stomach) were removed and analyzed through macroscopic inspection.

\section{Determination of LD50 value}

The LD50 value for $S$. brasiliensis CEE was determined through linear regression of the dose-response curves obtained after the treatment of each group of animals using the program GraphPad Prism 5.0.

\section{RESULTS}

\section{Acute toxicity and behavioral observations}

No significant differences in clinical signs of toxicity were observed between the animals treated with CEE of Siolmatra brasiliensis (Cogn.) Baill., Cucurbitaceae, at the doses of 10 and $100 \mathrm{mg} / \mathrm{kg} b w$ and the control (Table 1). On the other hand, the animals that 
received 1000 and $2000 \mathrm{mg} / \mathrm{kg} b w$ presented several behavioral alterations mainly right after administration, such as: increased urination and defecation, loss of righting reflex, ataxia, eyelid ptosis, reduced motor activity, and respiratory alterations. Furthermore, $S$. brasiliensis CEE caused dose-dependent mortality at the median lethal dose (LD50) of $1000 \mathrm{mg} / \mathrm{kg} \mathrm{bw}$. At the acute doses of 1000 and $2000 \mathrm{mg} / \mathrm{kg}$ bw, three and five out of six mice died within $24 \mathrm{~h}$, respectively.

\section{Macroscopic inspection}

During macroscopic inspection of the organs removed from mice that received $S$. brasiliensis CEE at the doses of 10 and $100 \mathrm{mg} / \mathrm{kg} \mathrm{bw}$, the appearance of heart, lungs, stomach, intestine, liver, and kidney were carefully monitored and no characteristics different from normal were seen. The animals treated with 1000 and $2000 \mathrm{mg} / \mathrm{kg} \mathrm{bw}$ presented morphologic alterations only in the heart.

\section{DISCUSSION}

Although medicinal plants may produce several biological activities in humans, generally very little is known about their toxicity (Tomlinson \& Akerele, 1998). Consequently, numerous works have been published signaling the potential toxicological effects that these products could also possess (Marcus \& Snodgrass, 2005; Pak et al., 2004) Therefore, the investigation of the acute toxicity is the first step in the toxicological analysis of herbal drugs (Lorke, 1983).

In this study, the LD50 value (Figure 1) of Siolmatra brasiliensis (Cogn.) Baill., Cucurbitaceae, CEE administered intraperitoneally indicated that it has slightly toxic potential, since substances with LD50 between 500 and 5000 and between 5000 and $15000 \mathrm{mg} /$

\section{- Linear regression}

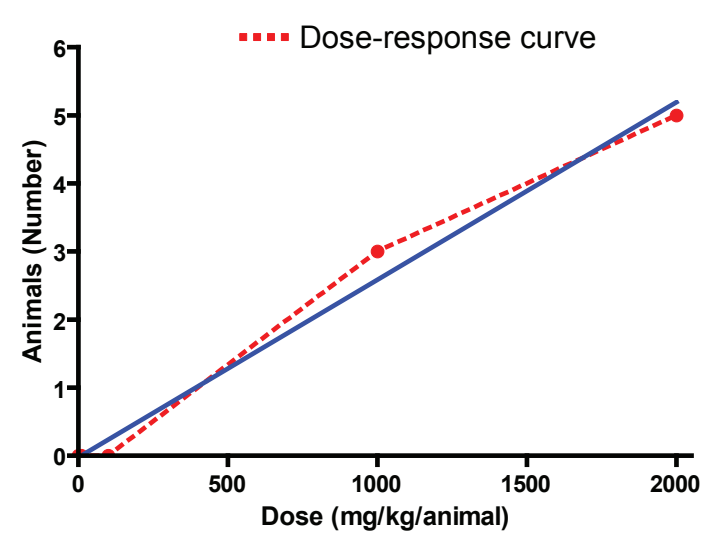

Figure 1. Determination of the DL50 value of Siolmatra brasilensis (Cogn.) Baill., Cucurbitaceae crude ethanolic extract administered intraperitoneally $(n=6)$. kg bw are considered slightly toxic and practically nontoxic, respectively (Loomis \& Hayes, 1996). Considering that population traditionally uses approximately 8 to $15 \mathrm{~g}$ of plant leaves from species of the family Cucurbitaceae, including Siolmatra brasiliensis, for preparation of medicinal potions (Balbachas, 1959, Dantas et al., 2008), and starting from the doses tested in present work, we suggest that a small portion of the active principles of the plant is consumed in form of potions, which leads to the conclusion that the final dose consumed by the population is much lower when compared to the LD50 $(1000 \mathrm{mg} / \mathrm{kg})$ obtained in this work.

In addition mortality, was observed signs of toxicity through the analysis of behavior after intraperitoneal administration of $S$. brasiliensis CEE at the doses of 1000 and $2000 \mathrm{mg} / \mathrm{kg} \mathrm{bw}$. These toxicity parameters included increased urination and defecation, loss of righting reflex, ataxia, eyelid ptosis, reduced motor activity, and irregular breathing. Some of these signs, such as loss of righting reflex, irregular breathing, and reduction of motor activity, may be the result of the potent CNS depressant activity caused by $S$. brasiliensis CEE in the large doses employed. The decrease in motor activity gives an indication of the level of excitability of the CNS (Masur et al., 1971). Some toxic effects have been detected in many species of the Cucurbitaceae family. Cucurbita ficifolia caused several signs of toxicity and high mortality rates in mice when administered both intraperitoneally and orally (Alarcon-Aguilar et al., 2002).

The macroscopic inspection of the organs removed from mice treated with $S$. brasiliensis CEE at the doses of 1000 and $2000 \mathrm{mg} / \mathrm{kg} \mathrm{bw}$ showed that the only organ presenting morphologic alterations was the heart, which exhibited significant change in tonicity in the inferior region, a characteristic toxic response to cardiotonic drugs such as digitalis (Roden, 1996) Digitalis compounds bring about an increase in the availability of activator $\mathrm{Ca}^{2+}$ in the heart cells, and this increased intracellular $\mathrm{Ca}^{2+}$ activity is sufficient to explain both the inotropic and arrhythmogenic effects of these drugs (Hauptman et al., 1999). These observations suggest that the CEE of $S$. brasiliensis might have had a positive inotropic effect in the heart of mice treated with it.

Nonetheless, the components of this plant CEE that are responsible for the toxic manifestations after intraperitoneal administration of the highest dose remain unknown. Toxicity and mortality may be the result of one or more phytochemicals present in the CEE of this plant. The slightly toxic potential of $S$. brasiliensis is likely to be the effect of cucurbitacins, a group of diverse triterpenoid substances well-known for their toxicity (Chen et al., 2005). Cucurbitacins are predominantly found in the family Cucurbitaceae and despite their toxicity, several species of plants in which they are found have been 
Table 1. Behavioral parameters of Balb/c mice observed at different times after treatment with ethanolic crude extract of Siolmatra brasiliensis (Cogn.) Baill., Cucurbitaceae.

\begin{tabular}{|c|c|c|c|c|c|c|c|c|c|c|}
\hline $\begin{array}{c}\text { Dose } \\
\text { (mg/kg bw) }\end{array}$ & $\begin{array}{l}\text { Time } \\
(\mathrm{min})\end{array}$ & Urination & Defecation & Piloerection & Motor activity & Ataxia & $\begin{array}{l}\text { Righting } \\
\text { reflex }\end{array}$ & $\begin{array}{c}\text { Muscular } \\
\text { tonus }\end{array}$ & $\begin{array}{c}\text { Eyelid } \\
\text { ptosis }\end{array}$ & Death (n) \\
\hline \multirow{6}{*}{ Control } & 5 & $\mathrm{~N}$ & $\mathrm{~N}$ & NP & NP & $\mathrm{NP}$ & $\mathrm{N}$ & NP & NP & 0 \\
\hline & 15 & $\mathrm{~N}$ & $\mathrm{~N}$ & NP & NP & NP & $\mathrm{N}$ & NP & NP & 0 \\
\hline & 60 & $\mathrm{~N}$ & $\mathrm{~N}$ & $\mathrm{NP}$ & $\mathrm{NP}$ & $\mathrm{NP}$ & $\mathrm{N}$ & $\mathrm{NP}$ & NP & 0 \\
\hline & 120 & $\mathrm{~N}$ & $\mathrm{~N}$ & NP & NP & NP & $\mathrm{N}$ & NP & NP & 0 \\
\hline & 240 & $\mathrm{~N}$ & $\mathrm{~N}$ & NP & NP & NP & $\mathrm{N}$ & NP & NP & 0 \\
\hline & 1440 & $\mathrm{~N}$ & $\mathrm{~N}$ & NP & $\mathrm{NP}$ & NP & $\mathrm{N}$ & NP & $\mathrm{NP}$ & 0 \\
\hline \multirow{6}{*}{10} & 5 & $\mathrm{~N}$ & $\mathrm{~N}$ & NP & NP & NP & $\mathrm{N}$ & NP & NP & 0 \\
\hline & 15 & $\mathrm{~N}$ & $\mathrm{~N}$ & $\mathrm{NP}$ & NP & $\mathrm{NP}$ & $\mathrm{N}$ & NP & NP & 0 \\
\hline & 60 & $\mathrm{~N}$ & $\mathrm{~N}$ & NP & NP & $\mathrm{NP}$ & $\mathrm{N}$ & $\mathrm{NP}$ & NP & 0 \\
\hline & 120 & $\mathrm{~N}$ & $\mathrm{~N}$ & $\mathrm{NP}$ & $\mathrm{NP}$ & $\mathrm{NP}$ & $\mathrm{N}$ & $\mathrm{NP}$ & $\mathrm{NP}$ & 0 \\
\hline & 240 & $\mathrm{~N}$ & $\mathrm{~N}$ & NP & NP & NP & $\mathrm{N}$ & NP & NP & 0 \\
\hline & 1440 & $\mathrm{~N}$ & $\mathrm{~N}$ & NP & NP & NP & $\mathrm{N}$ & NP & NP & 0 \\
\hline \multirow{6}{*}{100} & 5 & $\mathrm{~N}$ & $\mathrm{~N}$ & $\mathrm{NP}$ & $\mathrm{NP}$ & $\mathrm{NP}$ & $\mathrm{N}$ & $\mathrm{NP}$ & $\mathrm{NP}$ & 0 \\
\hline & 15 & $\mathrm{~N}$ & $\mathrm{~N}$ & NP & NP & $\mathrm{NP}$ & $\mathrm{N}$ & NP & NP & 0 \\
\hline & 60 & $\mathrm{~N}$ & $\mathrm{~N}$ & NP & $\mathrm{NP}$ & $\mathrm{NP}$ & $\mathrm{N}$ & $\mathrm{NP}$ & NP & 0 \\
\hline & 120 & $\mathrm{~N}$ & $\mathrm{~N}$ & $\mathrm{NP}$ & NP & $\mathrm{NP}$ & $\mathrm{N}$ & $\mathrm{NP}$ & NP & 0 \\
\hline & 240 & $\mathrm{~N}$ & $\mathrm{~N}$ & $\mathrm{NP}$ & $\mathrm{NP}$ & $\mathrm{NP}$ & $\mathrm{N}$ & $\mathrm{NP}$ & $\mathrm{NP}$ & 0 \\
\hline & 1440 & $\mathrm{~N}$ & $\mathrm{~N}$ & NP & NP & NP & $\mathrm{N}$ & NP & NP & 0 \\
\hline \multirow{6}{*}{1000} & 5 & $\mathrm{~N}$ & $(+)$ & $\mathrm{NP}$ & $(-)$ & $\mathrm{P}$ & $(-)$ & $(-)$ & $\mathrm{P}$ & 0 \\
\hline & 15 & $(+)$ & $(+)$ & $\mathrm{NP}$ & $(-)$ & $\mathrm{P}$ & $(-)$ & $(-)$ & $\mathrm{P}$ & 0 \\
\hline & 60 & $(+)$ & $(+)$ & $\mathrm{NP}$ & $(-)$ & $\mathrm{P}$ & $(-)$ & $(-)$ & $\mathrm{P}$ & 0 \\
\hline & 120 & $\mathrm{~N}$ & $\mathrm{~N}$ & $\mathrm{NP}$ & $\mathrm{NP}$ & $\mathrm{NP}$ & $\mathrm{NP}$ & $\mathrm{NP}$ & $\mathrm{NP}$ & 3 \\
\hline & 240 & $\mathrm{~N}$ & $\mathrm{~N}$ & NP & NP & NP & NP & $\mathrm{NP}$ & NP & 0 \\
\hline & 1440 & $\mathrm{~N}$ & $\mathrm{~N}$ & NP & NP & $\mathrm{NP}$ & NP & $\mathrm{NP}$ & NP & 0 \\
\hline \multirow{6}{*}{2000} & 5 & $(+)$ & $(+)$ & NP & $(-)$ & $\mathrm{P}$ & $(-)$ & $(-)$ & $\mathrm{P}$ & 0 \\
\hline & 15 & $(+)$ & $(+)$ & NP & $(-)$ & $\mathrm{P}$ & $(-)$ & $(-)$ & $\mathrm{P}$ & 0 \\
\hline & 60 & $\mathrm{~N}$ & $\mathrm{~N}$ & NP & $\mathrm{N}$ & $\mathrm{P}$ & $(-)$ & $(-)$ & $\mathrm{P}$ & 3 \\
\hline & 120 & $\mathrm{~N}$ & $\mathrm{~N}$ & NP & NP & $\mathrm{NP}$ & NP & $\mathrm{NP}$ & $\mathrm{NP}$ & 1 \\
\hline & 240 & $\mathrm{~N}$ & $\mathrm{~N}$ & NP & NP & NP & NP & NP & NP & 1 \\
\hline & 1440 & $\mathrm{~N}$ & $\mathrm{~N}$ & $\mathrm{NP}$ & $\mathrm{NP}$ & $\mathrm{NP}$ & NP & $\mathrm{NP}$ & NP & 0 \\
\hline
\end{tabular}

N: Normal; NP: not present; P: present; (-): decreased; (+): increased.

used for centuries in various pharmacopeias. A number of compounds of this group have been investigated for their cytotoxic, hepatoprotective, anti-inflammatory, and cardiovascular effects (Miró, 1995).

In conclusion, this study suggests that $S$. brasiliensis CEE seemed to be safe at low doses (10 and $100 \mathrm{mg} / \mathrm{kg} \mathrm{bw}$ ). However, at higher doses (1000 and $2000 \mathrm{mg} / \mathrm{kg} b w$ ), some adverse effects were observed. Therefore, considering the results herein obtained for $S$. brasiliensis $\mathrm{CEE}$, the great consumption of this plant by the brazilian population, and the lack of scientific results that testify its spectrum of pharmacological activity and toxicological properties, studies on this plant chronic toxicity, mutagenicity, and cardiovascular effects should be carried out.

\section{REFERENCES}

Alarcon-Aguilar FJ, Hernandez-Galicia E, Campos-Sepulveda AE 2002. Evaluation of the hypoglycemic effect of Cucurbita ficifolia Bouché (Cucurbitaceae) in different experimental models. J Ethnopharmacol 82: 185-189.

Almeida A, Cardoso REF, Azevedo NR, Faria LC, Klein VLG, Rezende MH 2004. Anatomia caulinar e atividade antibacteriana de Siolmatra brasiliensis (Cogn.) Baill. (Cucurbitaceae) monitorada por bioautografia. $55^{\circ}$ Congresso Nacional de Botânica e $26^{\circ}$ Encontro Regional de Botânicos de $M G, B A$ e ES.

Balbachas A 1959. As Plantas Curam. São Paulo: Missionária.

Calixto JB 2000. Efficacy, safety, quality control, marketing and regulatory guidelines for herbal medicines phytotherapeutic agents. Braz J Med Biol Res 33: 179- 
189.

Capasso R, Izzo AA, Pinto L, Bifulco T, Vitobello C, Mascolo N 2000. Phytotherapy and quality of herbal medicines. Fitoterapia 71: 58-65.

Chen JC, Chiu MH, Nie RL Cordell GA, Qui SX 2005. Cucurbitacins and Cucurbitane glycosides: structures and biological activities. Nat Prod Rep 22: 386-389.

Cronquist A 1992. Integrated system of classification offlowering plants. New York: Columbia University Press.

Dantas VS, Dantas IC, Chaves TP, Felismino DC, Silva H, Dantas GDS 2008. Análise das garrafadas indicadas pelos raizeiros na cidade de Campina Grande-PB. Biofar 3: 7-13.

Gomes-Klein VL 1996. Cucurbitaceae do Estado do Rio de Janeiro: Subtribo Melothriinae E. G. O. Muell et F. Pax. Arq Jard Bot 34: 93-172.

Hauptman PJ, Garg R, Kelly RA 1999. Cardiac glycosides in the next millennium. Prog Cardiovasc Dis 41: 247-254.

Heywood VH 1979. Flowering plants of the world. London: Oxford University.

Lima AP, Pereira FC, Vilanova-Costa, CAST, Silveira-Lacerda EP, Ribeiro ASBB 2006. Avaliação da atividade antitumoral e citotóxica da planta Siolmatra brasiliensis. Rev Eletrônica de Farm 3: 10-12.

Loomis TA, Hayes AW 1996. Loomis's essentials of toxicology. New York: Academic Press.

Lorke D 1983. A new approach to practical acute toxicity testing. Arch Toxicol 54: 275-287.

Marcus DM, Snodgrass WR 2005. Do no harm: Avoidance of herbal medicines during pregnancy. Obstet Gynecol 105: 1119-1122.

Masur J, Martz RMW, Carlini EA 1971. Effects of acute and chronic administration of Cannabis sativa and $(-) \Delta^{9}-$ trans-tetrahydrocannabinol on behavior of rats in openfield arena. Psychopharmacology 19: 338-397.

Miró M 1995. Cucurbitacins and their pharmacological effects. Phytother Res 9: 159-168.

Pak E, Esrason KT, Wu VH 2004. Hepatotoxicity of herbal remedies: an emerging dilemma. Prog Transplant 14: 91-96.

Robinson GL, Wunderlin RP 2005. Revision of Siolmatra (Cucurbitaceae Zanoniae). Contrib Bot 21: 1961-1969.

Roden DM 1996. Fármacos antiarrítmicos. In Hardman JG, Limbird LE As bases farmacológicas da terapêtica 9 . ed. Rio de Janeiro: McGraw-Hill, p. 616-642.

Simões CMO, Mentz LA, Schenkel EP, Irgang BE and Stehmann JR 1998. Plantas da Medicina Popular no Rio Grande do Sul. Porto Alegre: UFRGS.

Siqueira JM, Gazola AC, Farias MR, Volkov L, Rivard $\mathrm{N}$, de Brum-Fernandes AJ, Ribeiro-do-Valle RM 2009. Evaluation of the antitumoral effect of dihydrocucurbitacin-B in both in vitro and in vivo models. Cancer Chemoth Pharm 36: 360-366.

Talalay P, Talalay P 2001. The importance of using scientific principles in the development of medicinal agents from plants. Acad Med 76: 238-247.
Tomlinson TR, Akerele O 1998. Medicinal plants: their role in health and biodiversity. Philadelphia: University of Pennsylvania Press.

Vogel HG, Vogel WH 1997. Drug Discovery and Evaluation: Pharmacological Assays. Lewisville: J. A. Majors Company. 